\title{
ACUTE CALCIFIC TENDINITIS OF THE RECTUS FEMORIS
}

\author{
J. S. SARKAR, F. S. HADDAD, S. V. CREAN, P. BROOKS \\ From Lister Hospital, Stevenage, England
}

$\mathbf{W}$

e report six caucasian patients who had acute pain in the hip and marked limitation of all movements of the joint. Plain radiographs and CT of the pelvis showed calcification within the reflected head of rectus femoris. All six responded to accurate CT-controlled injections of corticosteroid and local anaesthetic with dramatic and prolonged pain relief, although one required a second injection for recurrence of symptoms after two months.

J Bone Joint Surg [Br] 1996;78-B:814-6.

Received 21 November 1995; Accepted after revision 23 February 1996

Painful periarticular calcification is most commonly seen within the rotator cuff of the shoulder (Neviaser 1983), although it may develop around the wrist, elbow, hip, knee, foot and rarely in the neck (Benanti et al 1986; Cox and Paterson 1991; Dilley and Tonkin 1991). The deposits may be located within the tendon or in the soft tissues adjacent to the tendon or ligament near its attachment to the bone. There is an acute inflammatory reaction, with pain, exquisite tenderness, local swelling and redness. Misdiagnosis is common and leads to delay in treatment and recovery (Johnson and Guly 1994).

At the hip, trochanteric tendinitis with calcification is well described (LeCocq 1931). It may affect the tendons of the abductors of the hip or even the origin of the vastus lateralis at the distal margin of the trochanter. It usually causes pain in the posterolateral aspect of the thigh which may simulate radicular pain from a prolapsed intervertebral disc.

We report six patients with calcific tendinitis in the reflected head of rectus femoris. This has been described previously (Archer et al 1992; Pope and Keats 1992; Holt and Keats 1993), but the clinical and radiological response to CTguided injection of steroid and local anaesthetic has not.

\section{PATIENTS AND METHODS}

From January 1993 to May 1994 six patients (Table I) were seen at the Lister Hospital with an acute onset of pain in the hip and inability to bear weight on the affected side. None had a history of previous problems in the hip or of any injury of note. The affected hips were held in $20^{\circ}$ to $30^{\circ}$ of flexion and all movements were limited by pain. The ESR,

Table I. Details of six patients with calcific tendinitis of rectus femoris

\begin{tabular}{|c|c|c|c|c|c|c|c|c|}
\hline Case & $\begin{array}{l}\text { Age } \\
(\mathbf{y r})\end{array}$ & Sex & Injury & $\begin{array}{l}\text { Time to } \\
\text { presentation } \\
\text { (days) }\end{array}$ & $\begin{array}{l}\text { Admitted to } \\
\text { hospital }\end{array}$ & $\begin{array}{l}\text { Response to } \\
\text { injection }\end{array}$ & $\begin{array}{l}\text { Absence of } \\
\text { calcification }\end{array}$ & Comments \\
\hline 1 & 43 & $\mathrm{~F}$ & None & 2 & No & $\begin{array}{l}\text { Partial resolution } \\
\text { of symptoms }\end{array}$ & 12 & $\begin{array}{l}\text { Needed reinjection } \\
\text { at } 6 \text { weeks }\end{array}$ \\
\hline 2 & 30 & $\mathrm{~F}$ & None & $<1$ & Yes & Immediate & 6 & \\
\hline 3 & 41 & M & Picking up shopping & $<1$ & No & Immediate & 12 & \\
\hline 4 & 36 & $\mathrm{~F}$ & None & $<1$ & Yes & $\begin{array}{l}\text { Relief of pain but } \\
\text { discomfort in thigh } \\
\text { for } 3 \text { days }\end{array}$ & 6 & \\
\hline 5 & 49 & M & None & 4 & Yes & Immediate & 6 & \\
\hline 6 & 45 & $\mathrm{~F}$ & Climbing stairs & 2 & No & Immediate & 8 & \\
\hline
\end{tabular}

J. S. Sarkar, MD, FRCS, Associate Specialist in Orthopaedics

F. S. Haddad, BSc, FRCS, Registrar in Orthopaedics

S. V. Crean, BDS, MB BS, FDS, Senior House Officer in Orthopaedics

P. Brooks, DMRD, FRCR, Consultant Radiologist

Lister Hospital, Coreys Mill Lane, Stevenage, Hertfordshire SG1 4AB, UK.

Correspondence should be sent to Mr F. S. Haddad at 46B Hanover Gate Mansions, Park Road, London NW1 4SN, UK.

(C)1996 British Editorial Society of Bone and Joint Surgery 0301-620X/96/51242\$2.00 the Rheumatoid Latex test, and the serum uric acid and Creactive protein levels were within normal limits. Radiographs of the hip revealed an area of calcification close to the superior lip of the acetabulum in all cases (Fig. 1). Three of the patients required admission to hospital for control of pain, which was achieved with intramuscular pethidine and oral non-steroidal anti-inflammatory agents. Subsequent CT confirmed the presence of calcification 


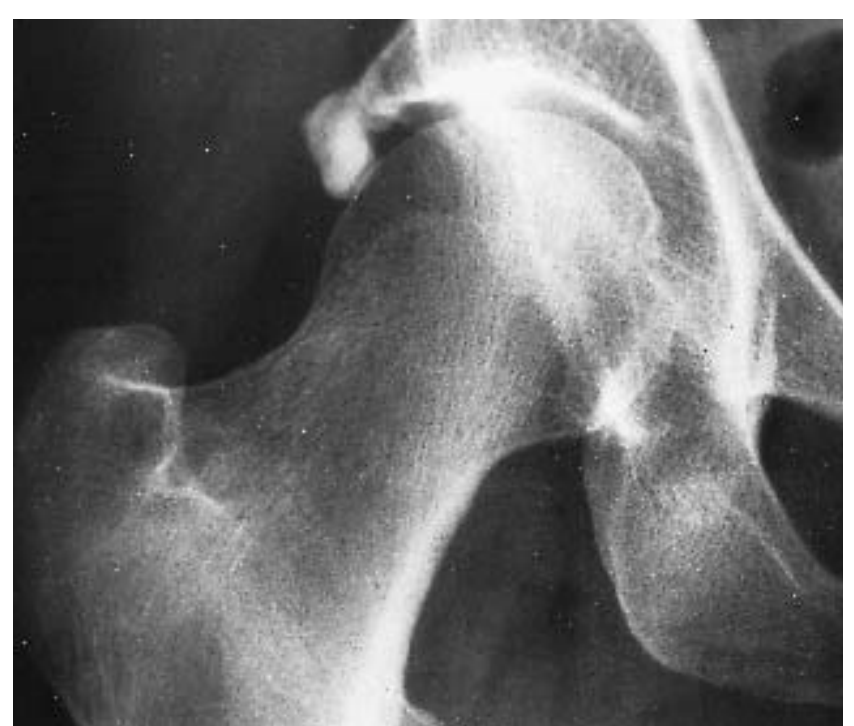

Fig. 1

AP view showing calcification near the superior lip of the acetabulum.

within the reflected head of rectus femoris in all six patients (Fig. 2), and excluded an intra-articular lesion. Under CT control, a 22-gauge spinal needle was positioned within the calcification and $80 \mathrm{mg}$ of methylprednisolone in combination with $2 \mathrm{ml}$ of $0.5 \%$ bupivacaine were injected (Fig. 3).

\section{RESULTS}

After injection, all patients obtained dramatic relief from pain and were discharged the next day. One had a recurrence two months later and received a second injection with complete relief; she was free from pain one year later. The others had no recurrence after six months. Further radiographs revealed complete disappearance of the calcification by six weeks in four patients (Fig. 4) and by 12 weeks in the other two.

\section{DISCUSSION}

Goldenberg and Leventhal (1936) reviewed the radiographs of 550 adult hips and found calcified deposits near the greater trochanter in $30(5.4 \%)$. They concluded that the calcification occurred at three sites, namely in the tendon of gluteus medius, in the bursa between the tendon of gluteus medius and the greater trochanter and in the undersurface of gluteus medius but not connected to the trochanter. Blundell Jones (1955) reported seven patients with an acute onset of pain in the hip and periarticular calcification. All were managed conservatively with persistence of symptoms for at least two weeks. Using stereoscopic radiographs he identified the site of calcification as the gluteus medius in one patient and beneath it or in the capsule in the others. Review of the radiographs shown in his paper suggests that some of these lesions may have been within rectus femoris.

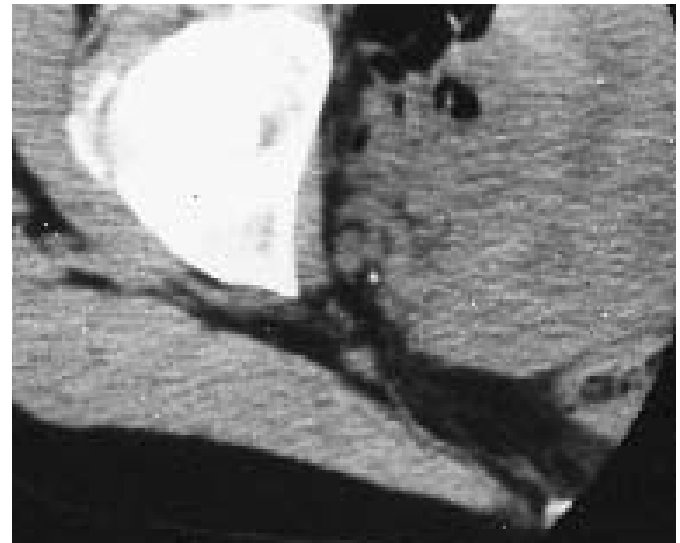

Fig. 2

CT of the right hip showing calcification within the reflected head of rectus femoris.

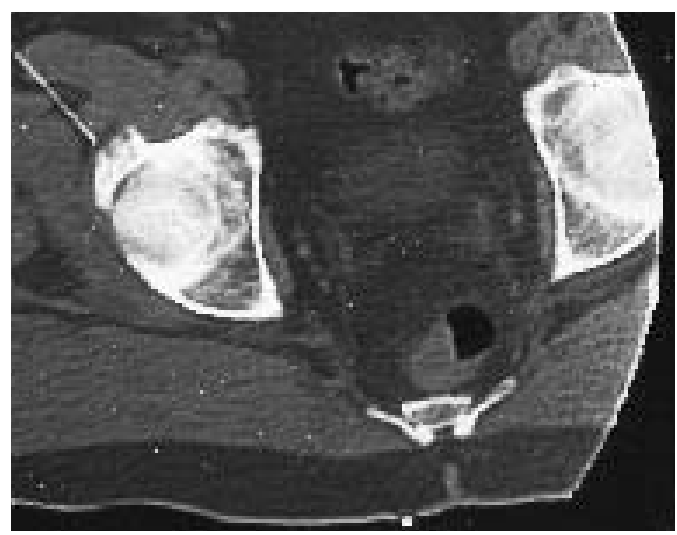

Fig. 3

CT-guided injection into the calcific deposit within the tendon.

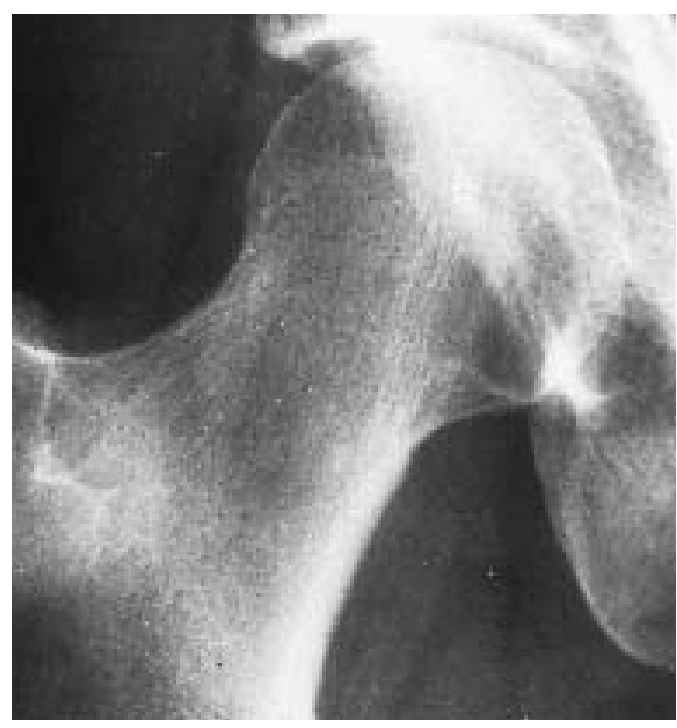

Fig. 4

AP view of the same hip as in Figure 1 showing complete resolution of the calcification at six weeks. 
In our series, calcification was noted in the reflected head of rectus femoris close to the capsule of the hip. The physical signs were those of acute synovitis of the hip, suggesting that the deposit in the tendon may have ruptured into the hip to precipitate the acute episode (Blundell Jones 1955).

Calcific tendinitis of rectus femoris has been reported previously (Archer et al 1992; Pope and Keats 1992; Holt and Keats 1993) and has usually been treated with oral nonsteroidal anti-inflammatory agents, although radiotherapy has also been used (King and Vanderpool 1967). The symptoms have usually resolved over the course of a few weeks (Blundell Jones 1955; Pope and Keats 1992; Holt and Keats 1993).

The differential diagnosis of calcification in the region of rectus femoris includes os acetabuli, avulsion fractures, sesamoid bones in the tendon of rectus femoris and myositis ossificans. A comet-tail appearance of the calcific deposit suggests that it lies within a tendon. Malignancies such as juxtacortical chondroma, chondrosarcoma and synovial sarcoma must be considered but CT allows proper visualisation and localisation of the lesion (Hodge et al 1993) and facilitates accurate injection if required.

The exact mechanisms of the origin and of resorption of the calcium deposits are not clearly understood. Schein and Lehmann (1941) proposed that a preceding injury to the tendon could provoke healing by calcification rather than by scarring. Carroll, Sinton and Garcia (1955) suggested 'local stress necrosis' as the cause of the deposition of calcium salts, either directly or through fatty-acid and soap intermediaries. Uhthoff, Sarkar and Maynard (1976), after histological studies of patients treated by operation, proposed local hypoxia secondary to either mechanical or vascular factors as the causative factor. Degeneration of tendon substance into fibrocartilage and subsequent calcification, mediated by chondrocytes, are followed by vascular proliferation and subsequent resorption of the deposits by macrophages, which restores normal perfusion and oxygen tension to the tissue. After resorption of the calcium, the tendon probably regains its original architecture by the synthesis of new matrix, so that no functional impairment remains. It is suggested that chemical dissolution of the inorganic material is not responsible for the acute phase of resorption which probably depends on a change in the bonding capacity of the organic molecules. This initiates phagocytosis in the resorptive phase (Gärtner and Simons 1990).

We are unable to explain the clustering of six patients with a rare condition in one area; we treated only one further case in the year after the study. Prompt diagnosis and early treatment with local injection of corticosteroid under CT control were successful in relieving symptoms in all these patients.

No benefits in any form have been received or will be received from a commercial party related directly or indirectly to the subject of this article.

\section{REFERENCES}

Archer BD, Friedman L, Stilgenbauer S, Bressler H. Symptomatic calcific tendinitis at unusual sites. Can Assoc Radiol J 1992;43: 203-7.

Benanti JC, Gramling P, Bulat PI, Chen P, Lundstrom G. Retropharyngeal calcific tendinitis: report of five cases and review of the literature. J Emerg Med 1986;4:15-24.

Blundell Jones G. Acute episodes with calcification around the hip joint. J Bone Joint Surg [Br] 1955;37-B:448-52.

Carroll RE, Sinton WA, Garcia A. Acute calcium deposit in the hand. JAMA 1955;157:422-6.

Cox D, Paterson FWN. Acute calcific tendinitis of peroneus longus. $J$ Bone Joint Surg [Br] 1991;73-B:342.

Dilley DF, Tonkin MA. Acute calcific tendinitis in the hand and wrist. J Hand Surg Br 1991;16:215-6.

Gärtner J, Simons B. Analysis of calcific deposits in calcifying tendinitis. Clin Orthop 1990;254:111-20.

Goldenberg RR, Leventhal GS. Supratrochanteric calcification. J Bone Joint Surg 1936;18:205-11.

Hodge JC, Schneider R, Freiberger RH, Magid SK. Calcific tendinitis in the proximal thigh. Arthr Rheum 1993;36:1476-82.

Holt PD, Keats TE. Calcific tendinitis: a review of the usual and unusual. Skeletal Radiol 1993;22:1-9.

Johnson GS, Guly HR. Acute calcific periarthritis outside the shoulder: a frequently misdiagnosed condition. J Accid Emerg Med 1994;11: 198-200.

King JW, Vanderpool DW. Calcific tendonitis of the rectus femoris. Am J Orthop 1967;9:110-1.

LeCocq E. Peritrochanteric bursitis: report of a case. J Bone Joint Surg 1931;13:872-3.

Neviaser RJ. Painful conditions affecting the shoulder. Clin Orthop 1983;173:63-9.

Pope TL, Keats TE. Case report 733. Calcific tendinitis of the origin of the medial and lateral heads of the rectus femoris muscle and the anterior iliac spin. Skeletal Radiol 1992;21:271-2.

Schein AJ, Lehmann O. Acute trochanteric bursitis with calcification. Surgery 1941;9:771-9.

Uhthoff HK, Sarkar K, Maynard JA. Calcifying tendinitis: a new concept of its pathogenesis. Clin Orthop 1976;118:164-8. 